\title{
Određivanje zabranjene zone poluvodiča metodom UV-Vis difuzne refleksijske spektroskopije
}

\author{
S. Kurajica, ${ }^{a^{*}}$ V. Mandić, ${ }^{a}$ M. Tkalčević, ${ }^{b}$ K. Mužina, ${ }^{a}$ i I. K. Munda \\ a Sveučilište u Zagrebu, Fakultet kemijskog inženjerstva i tehnologije, Marulićev trg 19, Zagreb \\ b Institut Ruđer Bošković, Zavod za fiziku materijala, Bijenička cesta 54, Zagreb
}

\begin{abstract}
Sažetak vrijednosti širine zabranjene zone komentirana je točnost metode te osjetljivost pri razlikovanju poluvodiča s direktnim i indi-

Ključne riječi

Taucov grafički prikaz, zabranjena zona, difuzna refleksijska spektroskopija, poluvodiči, metalni oksidi
\end{abstract}

U radu je dan pregled pojmova i jednadžbi vezanih uz određivanje zabranjene zone metodom difuzne refleksijske spektroskopije i uporabu Taucova grafičkog prikaza. Kako bi se demonstrirao postupak i vrednovala sama metoda, primjenom metode određena je zabranjena zona komercijalnih uzoraka anatasa, rutila, cinkita i hematita. Na temelju eksperimentalno dobivenih rektnim prijelazima. Pokazano je da Taucova metoda nije besprijekorna niti u pogledu točnosti niti razlikovanja indirektnih i direktnih elektronskih prijelaza u poluvodičkim materijalima, ali je vrlo praktičan način određivanja širine zabranjene zone poluvodiča budući da ne zahtijeva pretjerano skupu instrumentaciju a obrada eksperimentalnih podataka relativno je jednostavna.

\section{Uvod}

\subsection{Energijske vrpce i zabranjena zona}

Zbog kvantno-mehaničkih ograničenja elektroni u atomima imaju točno određene energije, energijske razine. $U$ kristalnoj rešetci, koja se sastoji od brojnih atoma, energijske se razine cijepaju na bliska energijska stanja (slika 1). Zbog brojnosti i malih razlika u energiji ta se diskretna energijska stanja nazivaju energijskim vrpcama. Energijske vrpce su područja dopuštenih energijskih stanja elektrona u materijalu. Svojstva različitih materijala ovise o različitim energijama koje elektroni mogu poprimiti, ali u slučaju poluvodiča i o energijama koje elektroni ne mogu poprimiti, tj. područjima nedopuštenih energijskih stanja elektrona u materijalu, zabranjenim zonama, energijskim procijepima. ${ }^{1}$

Za opis elektronske strukture materijala najznačajnije su dvije vrpce najviše energije, valentna i vodljiva vrpca. Valentna vrpca je područje najviše energije elektrona pri kojima su oni još uvijek vezani za atom, dok je vodljiva vrpca područje najniže energije elektrona pri kojoj se oni slobodno kreću kroz kristalnu rešetku. Valentna vrpca može biti djelomično ili posve popunjena elektronima, dok je vodljiva vrpca prazna. Električnu vodljivost omogućuju slobodni nosioci naboja, elektroni i šupljine, koji se izloženi električnom polju počnu unutar vrpci kretati sukladno smjeru polja. Prazna elektronska vrpca ne može sudjelovati u tom procesu budući da u njoj nema elektrona. Elektronska

*Autor za dopisivanje: prof. dr. sc. Stanislav Kurajica e-pošta: stankok@fkit.hr

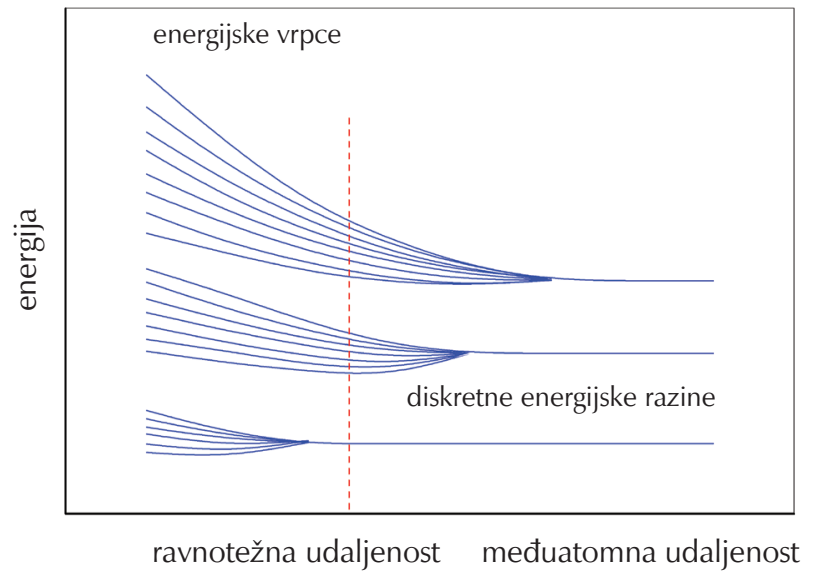

Slika 1 - Shematski prikaz nastanka energijskih vrpci

Fig. 1 - Schematic representation of energy bands formation

vrpca u potpunosti okupirana elektronima također ne doprinosi vodljivosti. ${ }^{2}$ Kako bi elektroni u posve popunjenoj valentnoj vrpci doprinijeli vodljivosti, oni moraju biti pobuđeni u vodljivu vrpcu. Pri tome u valentnoj vrpci ostaje nepopunjeno mjesto, šupljina, koja odgovara pozitivnom naboju i također doprinosi vodljivosti. Električna svojstva materijala definirana su stoga odnosima i popunjenošću elektronskih vrpci te se materijali prema električnim svojstvima mogu klasificirati u tri grupe: vodiče, poluvodiče i izolatore (slika 2). Vodiče karakterizira barem jedna djelomično popunjena vrpca. Takva elektronska struktura omogućuje kretanje elektrona, odnosno električnu vodljivost. 
Poluvodiče i izolatore karakterizira u potpunosti popunjena valentna i potpuno prazna vodljiva vrpca. Vrpce su odijeljene zabranjenom zonom ili energetskim procjepom, u kojoj ne postoje dopuštene energijske razine. Da bi postali slobodni, elektroni moraju prijeći iz valentne u vodljivu vrpcu za što moraju imati određenu minimalnu energiju potrebnu za svladavanje energijske razlike između vrpci. Ta minimalna energija koja odgovara razlici energije valentne i vodljive vrpce naziva se zabranjenom zonom, $E_{\mathrm{g}}$. Upravo je širina zabranjene zone kriterij za razlikovanje poluvodiča i izolatora. Naime, što je zabranjena zona šira, energija potrebna za njezino svladavanje bit će veća, a vjerojatnost da će termički pobuđeni elektroni imati dovoljno energije za prijelaz u vodljivu vrpcu manja. Zabranjena zona u izolatorima vrlo je široka; dijamant, primjerice, ima zabranjenu zonu od 5,5 eV. Zabranjena zona u poluvodičima je uža, po jednoj od definicija manja od 3 eV; silicij, primjerice, pri sobnoj temperaturi ima zabranjenu zonu od 1,1 eV. ${ }^{1}$ Kao mjernu jedinicu prikladnu za izražavanje malih vrijednosti energije upotrebljava se elektronvolt (eV). Definira se kao kinetička energija koju primi elektron u vakuumu ubrzan električnim poljem potencijalom od $1 \mathrm{~V}$. $1 \mathrm{eV}$ odgovara 1,60217653(14) $\cdot 10^{-19} \mathrm{~J}$.

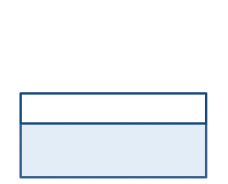

vodič

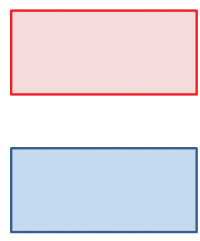

poluvodič

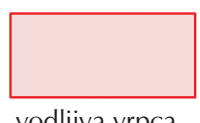

vodljiva vrpca

valentna vrpca

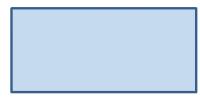

izolator
Slika 2 - Energijske vrpce vodiča poput bakra s djelomično popunjenom vrpcom, poluvodiča poput silicija s relativno uskom zabranjenom zonom i izolatora poput dijamanta sa širokom zabranjenom zonom

Fig. 2 - Energy bands of conductors such as copper with halffilled band, semiconductors such as silicon with a relatively narrow band gap, and insulators such as diamond with a wide band gap

Pri temperaturi apsolutne nule i u potpunom mraku poluvodič se ponaša kao izolator te ima u potpunosti popunjenu valentnu i potpuno praznu vodljivu vrpcu. Bez obzira na širinu zabranjene zone elektroni nemaju dovoljno energije za prijelaz u vodljivu vrpcu. Porastom temperature sve više elektrona će imati energiju dovoljnu za prijelaz zabranjene zone a sama zabranjena zona će se porastom temperature sužavati. Energiju za prijelaz zabranjene zone elektroni mogu steći i apsorpcijom fotona, pa će izlaganje poluvodiča zračenju čija je energija veća od zabranjene zone omogućiti prijelaz elektrona u vodljivu vrpcu. Prelaskom u valentnu vrpcu elektroni se mogu kretati i doprinose električnoj vodljivosti materijala. Prazna elektronska mjesta stvorena na taj način nazivaju se šupljinama. Šupljine mogu popunjavati elektroni susjednih atoma, čime se opet stvaraju šupljine u atomima iz kojih elektroni dolaze. Proces se, osim kao tijek elektrona, može opisati i kao kretanje šupljina u smjeru suprotnom od kretanja elektrona. ${ }^{2}$
I elektroni i šupljine nositelji su naboja i u poluvodiču bez primjesa, intrinsičnom poluvodiču te je njihova brojnost jednaka. S druge strane, u ekstrinsičnim poluvodičima, koji nastaju dopiranjem $\mathrm{s}$ atomima drugih elemenata, ima više elektrona ili šupljina ovisno o valenciji dopiranog atoma. Ako je valencija dopanda veća od valencije atoma dopiranog poluvodiča (primjerice As u odnosu na Si), poluvodič će imati suvišak elektrona, tzv. n-tip poluvodiča. U suprotnom slučaju, kada je valencija dopanda manja od valencije dopiranog poluvodiča (primjerice B u odnosu na Si), poluvodič će imati suvišak šupljina, tzv. p-tip poluvodiča. $\cup$ oba slučaja energija zabranjene zone bit će manja nego u slučaju čistog poluvodiča.

\subsection{Apsorpcija fotona}

Pri apsorpciji fotona dolazi do pobude elektrona, odnosno prelaska elektrona iz valentne u vodljivu vrpcu, pri čemu se u valentnoj vrpci stvaraju šupljine. Osim apsorpcije, pri srazu fotona i materijala može doći i do transmisije i refleksije (slika 3). Do koje će pojave doći, ovisi o energiji fotona, ali i o vrsti i debljini poluvodiča. Do apsorpcije će doći kada je energija fotona jednaka ili veća od zabranjene zone. U prvom slučaju foton ima upravo energiju potrebnu za ekscitaciju, dok u drugom slučaju foton ima više energije pa ekscitirani elektron otpušta razliku energije između energije fotona i zabranjene zone u vidu topline, odnosno vibracija kristalne rešetke, ili u vidu fotona, ostajući u energetskom stanju koje odgovara donjem rubu vodljive vrpce. Energija otpuštena u vidu topline, odnosno mehaničkih vibracija često se opisuje fononima, kvantnim kvazičesticama ili kvantima energije oscilacija atoma u kristalnoj rešetci analognima fotonu, kvantu elektromagnetskog titraja. S druge strane, do transmisije će doći ukoliko je energija fotona manja od zabranjene zone. Refleksija se, u principu, objašnjava kroz valnu, a ne čestičnu prirodu zračenja i to interakcijom upadnog zračenja s elektronima materijala, pri čemu oni postaju sekundarni izvori zračenja. ${ }^{3}$

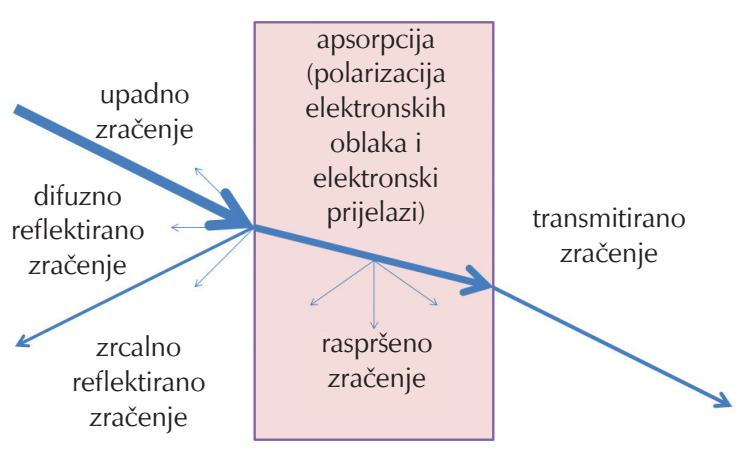

Slika 3 - Prikaz interakcije elektromagnetskog zračenja i materijala

Fig. 3 - Representation of the interaction between electromagnetic radiation and material

Odnosi između upadnog te apsorbiranog, transmitiranog i reflektiranog zračenja definirani su zakonom očuvanja energije. Ako se intenzitet upadnog zračenja označi s $I_{0}$, 
intenzitet apsorbiranog zračenja $\mathrm{s} I_{\mathrm{A}}$, intenzitet propuštenog (transmitiranog) zračenja $\mathrm{S} I_{\mathrm{T}} \mathrm{i}$ intenzitet reflektiranog zračenja $s I_{R}$, tada za slučaj normalnog upadnog snopa i za uzorak konačne debljine $d$ vrijedi jednadžba:

$$
I_{0}=I_{\mathrm{A}}+I_{\mathrm{T}}+I_{\mathrm{R}}
$$

Postoji još jedna pojava karakteristična za sraz zračenja i materijala; radi se o raspršenju, pojavi promjene smjera širenja zračenja zbog sudara s česticama u sredstvu. Raspršenje smanjuje transmisiju i povećava refleksiju, pa je na taj način uključeno u bilancu energije.

Zakon očuvanja energije zračenja može se napisati i u obliku:

$$
\alpha+\tau+\rho=1
$$

gdje je $\alpha$ apsorptancija, bezdimenzijska veličina jednaka omjeru toka zračenja apsorbiranog u mediju i ukupnog upadnog toka zračenja na površinu medija;

$$
\alpha=\frac{I_{\mathrm{A}}}{I_{0}}
$$

$\tau$, transmitancija, bezdimenzijska veličina jednaka omjeru toka zračenja koji je prošao kroz medij i ukupnog upadnog toka zračenja na površinu medija;

$$
\tau=\frac{I_{\mathrm{T}}}{I_{0}}
$$

te $\rho$, reflektancija, bezdimenzijska veličina jednaka omjeru toka zračenja reflektiranog iz medija i upadnog toka zračenja na površinu medija.

$$
\rho=\frac{I_{\mathrm{R}}}{I_{0}}
$$

Za idealno crno tijelo vrijedi: $\alpha=1, \rho=\tau=0$; za idealno bijelo tijelo vrijedi: $\rho=1, \alpha=\tau=0$, a za prozirna, neobojena tijela vrijedi: $\tau=1, \rho=\alpha=0$. U tim slučajevima koeficijenti $\alpha, \rho$ i $\tau$ nisu funkcije valne duljine u vidljivom dijelu spektra elektromagnetskog zračenja, tj. njihova vrijednost je u tom području konstantna. S druge strane, za potpuno neprozirna, obojena tijela $\alpha, \rho$ i $\tau$ su funkcije valne duljine $u$ vidljivom dijelu spektra elektromagnetnog zračenja, tj. njihova vrijednost se u tom području mijenja.

Apsorbancija je dekadski logaritam omjera intenziteta upadnog $\left(I_{0}\right)$ i transmitiranog zračenja $\left(I_{T}\right)$.

$$
A=\log \frac{I_{0}}{I_{\mathrm{T}}}
$$

Apsorbancija se matematički opisuje Lambert-Beerovim zakonom, koji se najčešće navodi u obliku prikladnom za apsorpciju u otopinama:

$$
A=\varepsilon C X
$$

gdje je A apsorbancija pri određenoj valnoj duljini svijetlosti, $\varepsilon$ je molarni ekstinkcijski koeficijent $\left(\mathrm{mol}^{-1} \mathrm{~cm}^{-1}\right) \mathrm{ka}-$ rakterističan za molekule otopljene tvari i ovisan o valnoj duljini svijetlosti, $c$ je koncentracija otopljene tvari $\left(\mathrm{moll}^{-1}\right)$ a $x(\mathrm{~cm})$ duljina puta svjetlosti kroz uzorak.

Ekstinkcijski koeficijent je mjera prigušenja intenziteta zračenja zbog apsorpcije i raspršenja, pa se uz zanemarivanje raspršenja i uzevši u obzir da je apsorbancija svojstvo materijala, može pisati: ${ }^{4}$

$$
A=\alpha x
$$

gdje je A apsorbancija pri određenoj valnoj duljini svjetlosti, $\alpha$ apsorpcijski koeficijent, svojstven materijalu i ovisan o valnoj duljini svjetlosti a $x$ duljina puta svjetlosti kroz materijal. Slijedi da intenzitet svjetlosti nakon prolaska kroz materijal iznosi:

$$
I=I_{0} \exp (-\alpha x)
$$

\subsection{Valni vektor}

Za proces apsorpcije fotona, osim energije, važan je i impuls fotona, odnosno elektrona. Budući da elektron osim čestične ima i valnu prirodu, karakterizira ga i valna duljina:

$$
\lambda=\frac{h}{\boldsymbol{p}^{\prime}}
$$

gdje je $h$ Planckova konstanta a $\boldsymbol{p}$ impuls elektrona. U procesu apsorpcije fotona (sudara fotona i elektrona), osim energije, mora biti očuvan i impuls. Fotoni imaju znatnu energiju, ali vrlo mali impuls (dok impuls fotona odgovara $h / \lambda$, energija odgovara $h c / \lambda$ ). Stoga fotoni prilikom ekscitacije iz valentne $u$ vodljivu vrpcu elektronima predaju značajnu energiju, dok kristalnoj rešetci predaju zanemariv impuls. Impuls elektrona u kristalnoj rešetci, kristalni impuls, definiran je valnim vektorom ili $k$ vektorom prema jednadžbi:

$$
\boldsymbol{p}=\hbar \boldsymbol{k}
$$

gdje je $\hbar$ reducirana Planckova konstanta a $\boldsymbol{k}$ valni ili $k$-vektor koji opisuje iznos i smjer napredovanja elektrona kao vala. Iznos valnog vektora obrnuto je proporcionalan valnoj duljini. Za razliku od izotropnog medija u kojem smjer valnog vektora odgovara smjeru napredovanja vala, u kristalnoj rešetci to ne mora biti tako.

U jednom smjeru u kristalnoj rešetci $\boldsymbol{k}$ je, zbog periodičnosti rešetke, također periodičan te se izvan područja $[0, \pi / a]$, gdje je a parametar jedinične ćelije, $\boldsymbol{k}$ ponavlja (slika 4). Međutim, $\boldsymbol{k}$ znatno ovisi o simetriji kristalne rešetke, pa će u drugom smjeru u jediničnoj ćeliji biti drugačiji. ${ }^{5}$

Energetska struktura vrpci u kristalu prikazuje se za vrijednosti k duž ravnih linija koje povezuju čvorove recipročne rešetke u kristalu. Recipročna rešetka je imaginarna rešetka koja se konstruira na temelju kristalne rešetke u realnom prostoru (direktne kristalne rešetke) i to tako da se iz zajedničkog ishodišta direktne kristalne rešetke povuku normale 


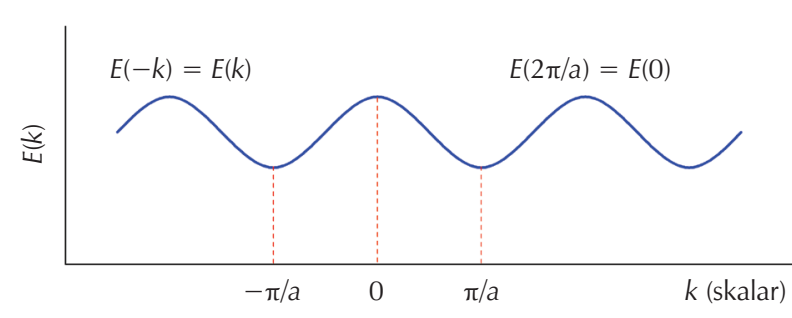

Slika 4 - Ovisnost $E(k)$ o $k$ za neki smjer u jediničnoj ćeliji

Fig. 4 - Dependence of $E(k)$ on $k$ for a possible direction in the unit cell

na mrežne ravnine. Dužina tih normala proporcionalna je recipročnoj vrijednosti međuplošnih razmaka. Točke na kraju normala definiraju recipročnu rešetku. Kada se promatrani čvor recipročne rešetke spoji sa susjednim čvorovima, ravnine koje raspolavljaju spojnice i na njih su okomite tvore granične plohe ćelije. Ta ćelija u recipročnom prostoru naziva se prvom Brillouinovom zonom.

Primjerice, kristalna struktura Si, koja odgovara strukturi dijamanta, sastoji se od dvije interpenetrirane plošno centrirane kubične rešetke (slika 5). Recipročni vektori te rešetke definiraju prostorno centriranu kubičnu rešetku. Prva Brillouinova zona u tom slučaju ima oblik krnjeg oktaedra s osam heksagonskih ravnina, koje se nalaze na polovici udaljenosti od centra do točaka u kutu i šest kvadratnih ravnina na polovici udaljenosti od centra do centra susjedne ćelije. Na slici 5 prikazana je prva Brillouinova zona kristalne rešetke silicija s točkama visoke simetrije označenima latiničnim slovima i linijama koje te smjerove povezuju označene slovima alfabeta. Tako $\Gamma$ odgovara ishodištu $k$ prostora, $X$ sredini kvadratnih ploha a $\Delta$ smjeru od $\Gamma$ do $X$ itd.

Maksimum valentne vrpce najčešće je $u$ ishodištu Brillouinove zone, odnosno u $\Gamma$ točki, dok se minimum vodljive vrpce, ovisno o simetriji kristala može nalaziti u $\Gamma$ točki, ali i u nekoj drugoj točki, primjerice X ili L.

\subsection{Direktni i indirektni prijelazi}

Impuls fotona neznatan je u usporedbi s valnim vektorom na rubu Brillouinove zone, pa zbog očuvanja impulsa elektroni s određenim valnim vektorom mogu prijeći samo u stanje u višoj vrpci s istim valnim vektorom. Prijelaz u stanje s različitim valnim vektorom moguć je samo uz sudjelovanje fonona.

Kada se maksimum valentne i minimum vodljive vrpce nalaze u istoj točki Brillouinove zone, primjerice $\Gamma$ točki, odnosno imaju jednak valni vektor, tada je prijelaz zabranjene zone direktan (slika 6a). Kad najniža energija vodljive vrpce i najviša energija valentne vrpce nemaju jednak valni vektor, odnosno kad su najniža energija vodljive vrpce i najviša energija valentne vrpce u dvije različite točke Brillouinove zone, radi se o indirektnom prijelazu zabranjene zone (slika 6b).

U slučaju direktnog prijelaza zabranjene zone elektron može prijeći iz najvišeg energetskog stanja valentne vrpce u najniže energetsko stanje vodljive vrpce bez promjene impulsa. Međutim, u slučaju indirektnog prijelaza zabranjene zone, pri prijelazu elektrona iz valentne u vodljivu vrpcu mora doći do promjene impulsa elektrona. $\mathrm{U}$ tom slučaju je energija potrebna za prijelaz elektrona iz valentne u vodljivu vrpcu veća od zabranjene zone.

Na slici 7 prikazane su energijske vrpce silicija koji je poluvodič $s$ indirektnim prijelazom (indirektni poluvodič) $\mathrm{i}$ galijeva arsenida koji je poluvodič $\mathrm{s}$ direktnim prijelazom (direktni poluvodič).

Slijedi da će u poluvodiču s direktnim prijelazom zabranjene zone do optičke apsorpcije doći samo apsorpcijom fotona (slika 6a), dok je u slučaju poluvodiča s indirektnim prijelazom zabranjene zone apsorpcija fotona praćena i emisijom ili apsorpcijom fonona (slika $6 \mathrm{~b}$ ). U tom slučaju mogući se proces odvija u dvama stupnjevima, u kojem elektron najprije prelazi iz maksimuma valentne vrpce u jednaku točku Brillouinove zone u hipotetskoj intermedijarnoj energijskoj razini. Elektron potom prelazi iz hipotetske intermedijarne a)

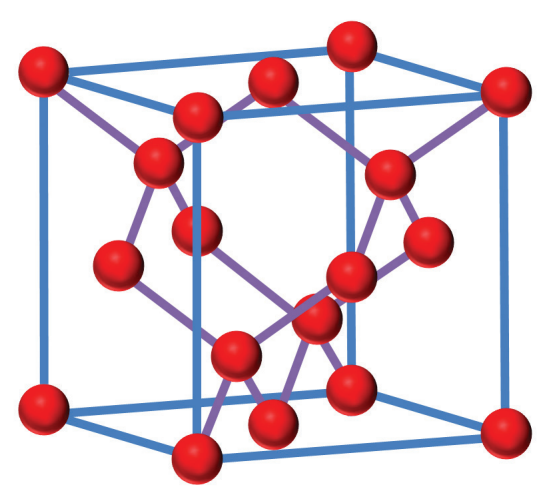

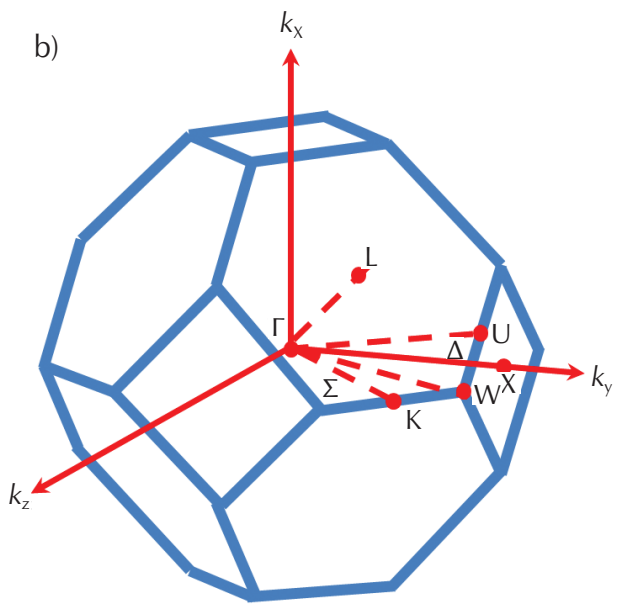

Slika 5 - a) Plošno centrirana kubična kristalna rešetka silicija i b) prva Brillouinova zona plošno centrirane kubične rešetke

Fig. 5 - a) Face-centred cubic silicon crystal lattice, and b) first Brillouin zone of face-centred cubic lattice 

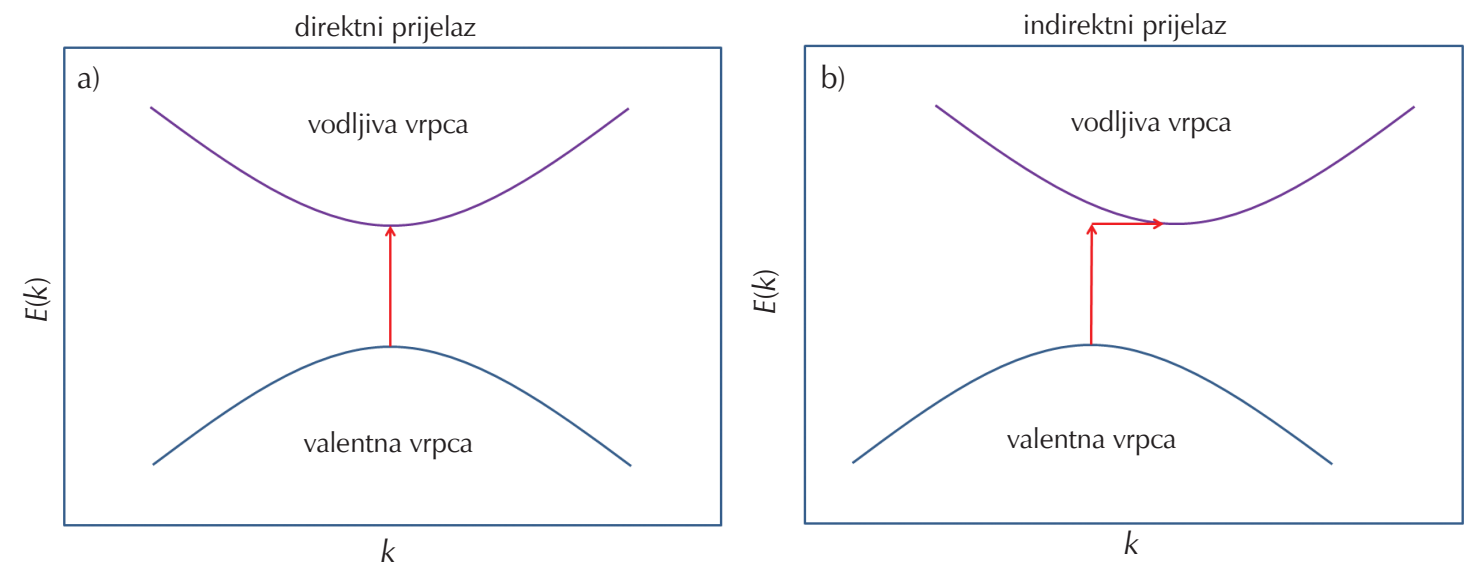

Slika 6 - Shematski prikaz ovisnosti $E(k)$ o $k$ za a) direktni i b) indirektni poluvodič. Na slikama su, također shematski, prikazani procesi direktne i indirektne tranzicije.

Fig. 6 - Schematic representation of the dependence of $E(k)$ on $k$ for a) direct and b) indirect semiconductor. The figures schematically show the processes of direct and indirect transition.
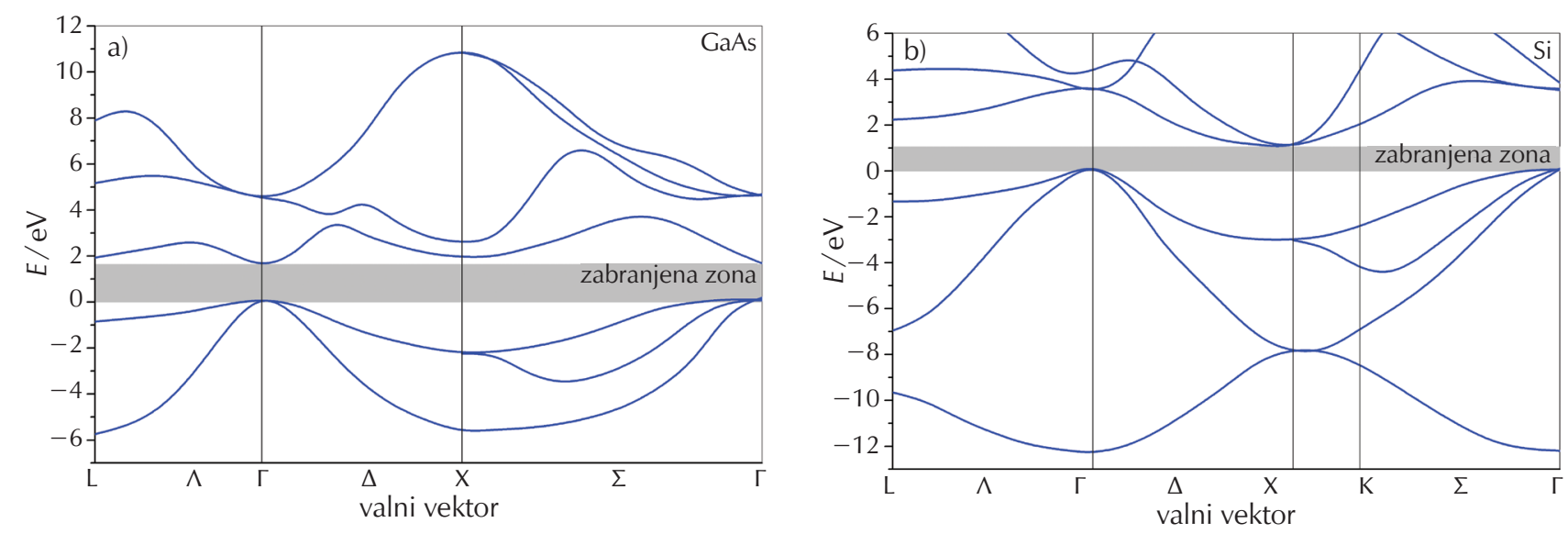

Slika 7 - Energijske vrpce a) GaAs (direktni poluvodič) i b) Si (indirektni poluvodič). Dijagrami sadrže više linija budući da postoji više dopuštenih energijskih stanja.

Fig. 7 - Energy bands of a) GaAs (direct semiconductor) and b) Si (indirect semiconductor). Diagrams contain more lines as there are more allowed energy states.

energijske razine $u$ minimum vodljive vrpce $u z$ apsorpciju fonona. Ako je minimum vodljive vrpce značajno udaljen od maksimuma valentne vrpce, razlika u energiji za tu elektronsku tranziciju je znatno veća od zabranjene zone, pa je indirektna tranzicija vrlo slaba. Budući da je za indirektnu tranziciju pored apsorpcije fotona potrebna i emisija ili apsorpcija fonona, indirektni su prijelazi manje vjerojatni od direktnih. Može se reći i da tijekom direktnog prijelaza valni vektor ostaje očuvan, dok tijekom indirektnog prijelaza dolazi do promjene valnog vektora uslijed interakcije s oscilacijama kristalne rešetke materijala, odnosno fononima.

\subsection{Određivanje zabranjene zone pomoću UV-Vis apsorpcijskog spektra}

Zabranjenu zonu pri direktnim i indirektnim prijelazima poluvodiča moguće je izračunati iz apsorpcijskog spektra materijala. ${ }^{6}$ Fotoni s energijom višom od zabranjene zone u stanju su ekscitirati elektron, te će u apsorpcijskom spektru u području valnih duljina nižih od valne duljine koja odgovara energiji zabranjene zone doći do snažne apsorpcije. $S$ druge strane, fotoni s energijom manjom od zabranjene zone nisu u stanju ekscitirati elektron, pa u području valnih duljina viših od valne duljine koja odgovara energiji zabranjene zone neće doći do apsorpcije. Slijedi da se grafički prikaz ovisnosti apsorpcijskog koeficijenta o energiji fotona (slika 8) sastoji od tri područja: ${ }^{7}$ a) područja slabe apsorpcije, pri čemu fotoni u tom području nemaju dovoljnu energiju za ekscitaciju elektrona iz valentne u vodljivu vrpcu; b) prijelaznog područja apsorpcije, koje energijski odgovara zabranjenoj zoni, u kojem dolazi do naglog porasta apsorpcije, pri čemu je koeficijent apsorpcije eksponencijalno ovisan o energiji upadnog fotona, c) područja snažne apsorpcije, pri čemu fotoni imaju energije veće od energije zabranjene zone poluvodiča, te su u stanju izazvati prijelaz elektrona iz valentne u vodljivu vrpcu poluvodiča. 


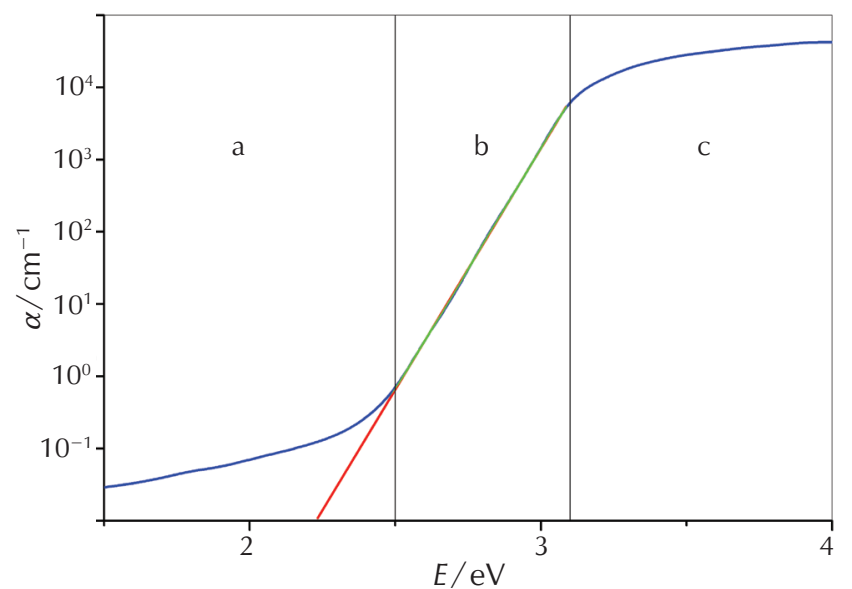

Slika 8 - Ovisnost apsorpcijskog koeficijenta o energiji fotona Fig. 8 -Dependence of the absorption coefficient on photon energy

Odnos apsorpcijskog koeficijenta, $\alpha$, i energije fotona ovisi o vrsti elektronskog prijelaza. Apsorpcijski koeficijent i zabranjena zona poluvodiča s direktnim prijelazom povezani su sljedećom jednadžbom: ${ }^{4}$

$$
\alpha h v=C_{1}\left(h v-E_{g}\right)^{1 / 2}
$$

Dok za poluvodič s indirektnim prijelazom vrijedi jednadžba: ${ }^{4}$

$$
\alpha h v=C_{1}\left(h v-E_{\mathrm{g}}\right)^{2},
$$

gdje je $\alpha$ linearni apsorpcijski koeficijent, $h v$ energija fotona upadnog zračenja a $C_{1}$ konstanta proporcionalnosti. Energija fotona upadnog zračenja je umnožak Planckove konstante $\left(6,626 \cdot 10^{-34} \mathrm{Js}\right.$, odnosno $\left.4,126 \cdot 10^{-15} \mathrm{eVs}\right) \mathrm{i}$ frekvencije $(v=c / \lambda)$ pa slijedi:

$$
\begin{aligned}
E=\frac{h c}{\lambda}= & \frac{4,13 \cdot 10^{-15}(\mathrm{eVs}) 2,99 \cdot 10^{8}\left(\mathrm{~m} \mathrm{~s}^{-1}\right)}{\lambda(\mathrm{m})}= \\
& =\frac{1,24 \cdot 10^{-6}(\mathrm{eVm})}{\lambda(\mathrm{m})}=\frac{1240(\mathrm{eVnm})}{\lambda(\mathrm{nm})} .
\end{aligned}
$$

Općenito se može pisati:

$$
(\alpha h v)^{n}=C_{1}\left(h v-E_{g}\right),
$$

gdje je $E_{\mathrm{g}}$ širina zabranjene zone a $n$ konstanta koja poprima vrijednosti 2 za direktni i $1 / 2$ za indirektni prijelaz. Navedene vrijednosti $n$ odnose se na dopuštene prijelaze. Naime, prema vjerojatnosti prijelaza i direktni i indirektni prijelazi dodatno se dijele na dopuštene i zabranjene, pa $n$ iznosi $3 / 2$ za zabranjeni direktni i 3 za zabranjeni indirektni prijelaz. Slijedi da će linearnost srednjeg dijela krivulje ovisnosti $(\alpha h v)^{n}$ o $h v$, odnosno energiji fotona, ukazivati na vrstu prijelaza. Primjerice, linearnost srednjeg dijela krivulje ovisnosti $(\alpha h v)^{2}$ o $h v$ ukazivat će na direktni prijelaz a zabranjena zona može se približno odrediti ekstrapolacijom linearnog dijela krivulje u prijelaznom području do presjeka s apscisom. ${ }^{8}$

\subsection{Difuzna refleksija}

Budući da za praškaste uzorke nije moguće mjeriti apsorbanciju, pribjegava se mjerenju reflektancije primjenom difuzne refleksijske spektroskopije. Razlikuje se zrcalna i difuzna refleksija (slika 9). Pri zrcalnoj refleksiji kut refleksije jednak je upadnom kutu te je ta vrsta refleksije tipična za glatke površine poput zrcala, poliranog metala ili mirne vode. Difuzna refleksija odlikuje se izotropnom distribucijom reflektiranog zračenja i karakteristična je za hrapave površine poput papira, tkanine ili zbijenog praška. Izotropna distribucija je posljedica višestruke refleksije i apsorpcije u sloju s debljinom dovoljnom za potpunu odsutnost transmitancije $\left(R=R_{\infty}\right)$. Na slici 9 prikazana je razlika dviju vrsta refleksije. Reflektancija pri difuznoj refleksiji, osim o indeksu loma, $n$, ovisi i o koeficijentu apsorpcije, $\alpha$, uzorka, koji opet ovisi o valnoj duljini zračenja i direktno je proporcionalan zrcalnoj refleksiji (pa je difuzna refleksija tim manja što je veći koeficijent apsorpcije).
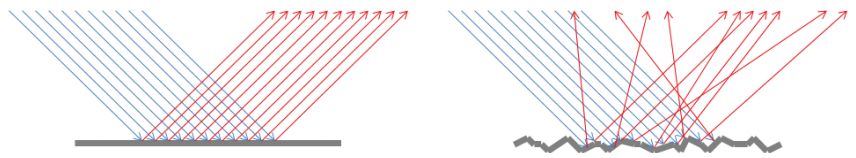

glatka površina - zrcalna refleksija hrapava površina - difuzna refleksija

Slika 9 - Zrcalna i difuzna refleksija. Svjetlo se može zamisliti kao snop paralelnih zraka. Svaka zraka reflektira se s površine sukladno zakonu refleksije (prema kojem je kut refleksije jednak upadnom kutu). Međutim, zrake ostaju paralelne samo kada se reflektiraju s glatke površine, dok do refleksije s hrapave, neravne površine dolazi u različitim smjerovima.

Fig. 9 - Specular and diffuse reflection. Light can be thought of as a beam of parallel rays. Each ray is reflected from the surface in accordance with the law of reflection (according to which the angle of reflection is equal to the incident angle). However, only when the surface is smooth, the reflected rays remain parallel, while reflection from the rough, uneven surface leads to reflection in different directions.

Mjerenje difuzne refleksije provodi se uz pomoć integrirajuće sfere koja se može nabaviti kao dodatak nekim modelima standardnih UV-Vis spektrometara (slika 10). Integrirajuća sfera omogućava značajno proširenje mogućnosti spektrometra od mjerenja transmitancije (apsorbancije) u otopinama i transparentnim čvrstim materijalima na mjerenje reflektancije opâkih (neprozirnih) čvrstih materijala, bilo kompaktnih bilo praškastih. Shematski prikaz principa rada integrirajuće sfere prikazan je na slici 11 . Uzorak se nalazi nasuprot otvora kroz koji zračenje ulazi u sferu, tako da zračenje pada izravno na uzorak. Na uzorku dolazi do refleksije (i apsorpcije), zračenje reflektirano s uzorka vi- 
šestruko se difuzno reflektira od stjenki sfere. Naposljetku jedan dio zračenja izlazi iz sfere i ulazi u detektor koji mjeri intenzitet zračenja. Zahvaljujući građi sfere, zračenje je jednoliko po sferi te je dio koji padne na detektor proporcionalan zračenju difuzno reflektiranom s uzorka. Osim same sfere, modul se sastoji i od nekoliko zrcala koja usmjeravaju upadnu zraku u sferu, slika 10. Cijeli modul relativno je jednostavno montirati u aparat a uzorak najčešće nije potrebno posebno obrađivati, već samo fiksirati u nosač. ${ }^{9}$

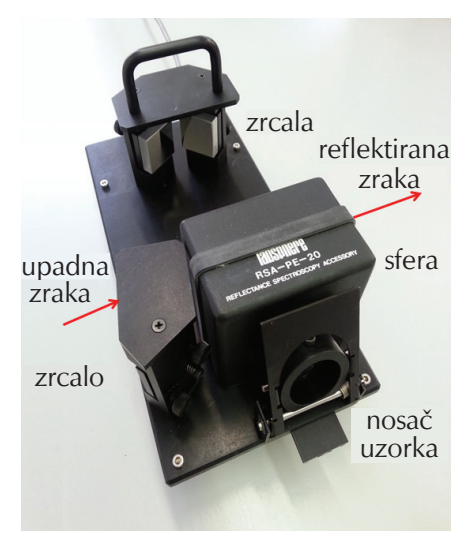

Slika 10 - Lambda 35 modul s integracijskom sferom proizvođača Perkin Elmer

Fig. 10 - Lambda 35 module with an integration sphere manufactured by Perkin Elmer

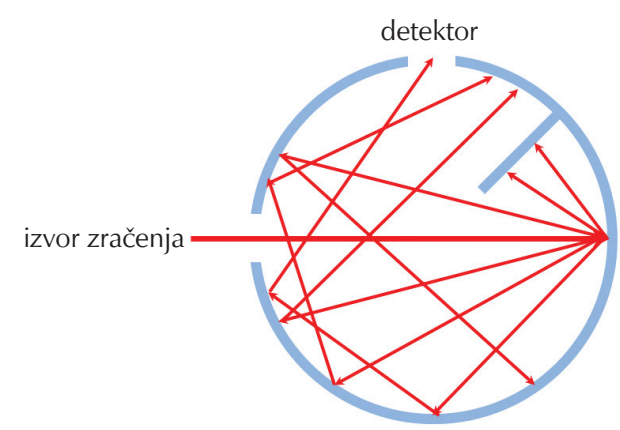

Slika 11 - Shematski prikaz integrirajuće sfere

Fig. 11 - Schematic representation of the integrating sphere

\subsection{Jednadžba Kubelke i Munka}

Difuzna refleksija opisuje se fenomenološkim modelom Paula Kubelke i Franza Munka koji za bilo koju valnu duljinu glasi: ${ }^{10}$

$$
\frac{K}{S}=\frac{\left(1-R_{\infty}\right)^{2}}{2 R_{\infty}} F\left(R_{\infty}\right),
$$

gdje su $K$ i $S$ Kubelka-Munkovi koeficijenti apsorpcije i raspršenja bez fizikalnog smisla, $R_{\infty}$ je reflektancija beskonačno debelog uzorka (u kojem debljina nema utjecaja na reflektanciju) a $F\left(R_{\infty}\right)$ Kubelka-Munkova (reemisijska) funk- cija. Ako materijal raspršuje svijetlost na savršeno difuzan način, Kubelka-Munkov koeficijent apsorpcije, $K$, postaje jednak $2 \alpha, K=2 \alpha$.

Apsolutnu vrijednost reflektancije nije moguće odrediti, pa se reflektancija određuje u odnosu na standard bjeline za koji se može smatrati da mu je reflektancija približno jednaka jedinici.

$$
R_{\infty}=\frac{R_{\text {uzorka }}}{R_{\text {standarda }}}
$$

Budući da je $K=2 \alpha$ a $S$ konstanta, slijedi: ${ }^{10}$

$$
\left[F\left(R_{\infty}\right) h v\right]^{2}=C_{2}\left(h v-E_{\mathrm{g}}\right)
$$

za direktni i:

$$
\left[F\left(R_{\infty}\right) h v\right]^{1 / 2}=C_{2}\left(h v-E_{\mathrm{g}}\right)
$$

za indirektni prijelaz.

Slijedi da se zabranjena zona praškastih uzoraka može odrediti iz grafičke ovisnosti $\left[F\left(R_{\infty}\right) h v\right]^{\mathrm{n}} \mathrm{o} h v$, odnosno $E$, tzv. Taucov grafički prikaz. ${ }^{7}$ Osnovni preduvjeti za provođenje eksperimenta slijede iz osnovnih pretpostavki Kubelke i Munka:

- Difuzna refleksija mora biti dominantna vrsta refleksije. Kako bi taj preduvjet bio ispunjen, površina ne smije biti sjajna jer se tako povećava udio zrcalne refleksije.

- lako površina treba biti hrapava, to ne znači da smije biti makroskopski neravna, budući da neravnine smanjuju difuznu refleksiju. Zbog toga se uzorci blago prešaju.

- Sloj mora biti dovoljne debljine kako ne bi bio transparentan. Minimalna debljina za ispunjenje tog uvjeta je $1 \mathrm{~mm}$.

Ako materijal pokazuje umjerenu apsorpciju, tada se raspršenje može pojačati smanjenjem dimenzija čestica. Time će se pojačati i udio difuzne refleksije. Ako materijal pokazuje snažnu apsorpciju, tada je dubina prodiranja mala, pa smanjenje dimenzija čestica ne doprinosi naročito raspršenju. U tom se slučaju raspršenje može povećati miješanjem uzorka s bijelim standardom.

\section{Eksperimentalni dio}

Analizirana su dva uzorka $\mathrm{TiO}_{2}$, proizvođača Merck (Njemačka) i proizvođača Tioxide (V. Britanija), te po jedan uzorak $\mathrm{ZnO}$, proizvođača Merck (Njemačka) i $\mathrm{Fe}_{2} \mathrm{O}_{3}$, proizvođača Sigma-Aldrich (SAD). Uzorci $\mathrm{TiO}_{2}$ i $\mathrm{ZnO}$ analizirani su u izvornom stanju, dok je uzorak $\mathrm{Fe}_{2} \mathrm{O}_{3}$ razrijeđen $\mathrm{s} \mathrm{BaSO}_{4}$ u omjeru $1: 4$.

Kristalne faze u uzorcima identificirane su rendgenskom difrakcijom praha. Upotrijebljen je Shimadzu XRD 6000 difraktometar s CuK $\alpha(\lambda=1,54059 \AA)$ zračenjem uz napon od $40 \mathrm{kV}$ i jakost struje od $30 \mathrm{~mA}$. Podatci su prikupljeni između 5 i $70{ }^{\circ} 2 \theta$ s korakom $0,02^{\circ}$ i zadržavanjem od 0,6 s po koraku. 

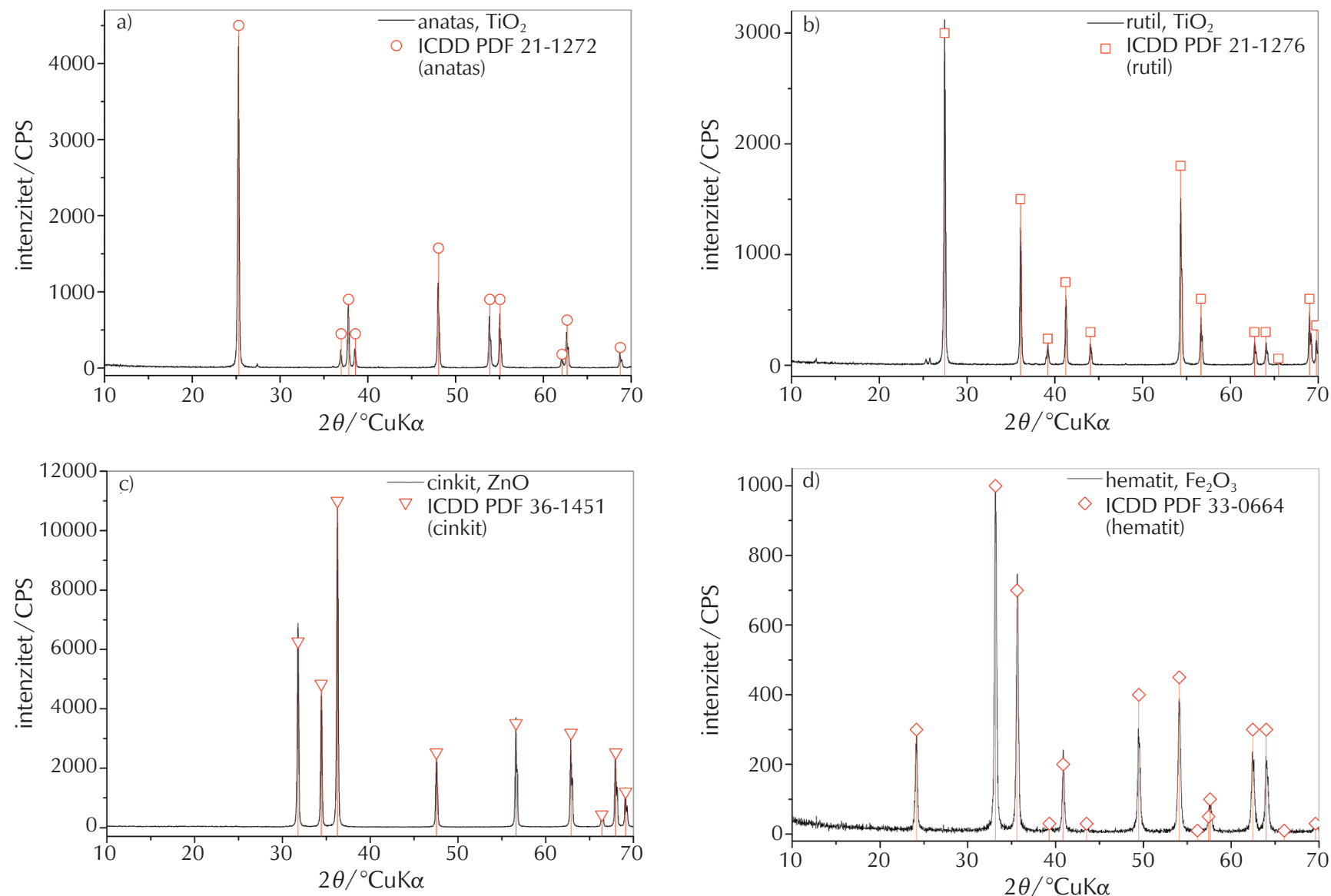

Slika 12 - Difraktogrami uzoraka: a) anatasa, b) rutila, c) cinkita i d) hematita

Fig. 12 - X-ray patterns of samples: a) anatase, b) rutile, c) zincite, and d) hematite

UV-Vis spektri istraživanih uzoraka dobiveni su spektroskopskom analizom u režimu potpune refleksije u uređaju Perkin-Elmer Lambda 35 uz upotrebu integrirajuće sfere (Labsphere RSA-PE-20). Barit $\left(\mathrm{BaSO}_{4}\right)$ je upotrijebljen kao standard bjeline. Za svaki uzorak provedena su najmanje tri mjerenja, a reflektancija je izražena kao aritmetička sredina.

Matematička obrada mjernih podataka i utočnjavanje na jednadžbu pravca provedeno je programom za izradu grafičkih prikaza i analizu podataka primjenom metode najmanjih kvadrata.

\section{Rezultati i rasprava}

Istraživani uzorci najprije su analizirani metodom rendgenske difrakcije a dobiveni difraktogrami prikazani su na slici 12. Utvrđeno je da se na difraktogramu uzorka $\mathrm{TiO}_{2}$ proizvođača Merck, uz difrakcijske maksimume anatasa, ICDD PDF \#21-1272, primjećuje i jedan slab difrakcijski maksimum rutila te je fazni sastav tog uzorka pretežito anatas s tragovima rutila. Na difraktogramu uzorka $\mathrm{TiO}_{2}$ proizvođača Tioxide se, uz difrakcijske maksimume rutila, ICDD PDF \#21-1276, pojavljuje nekoliko slabih difrakcijskih maksimuma anatasa te je fazni sastav tog uzorka pretežito rutil s tragovima anatasa. Nadalje je utvrđeno da je uzorak $\mathrm{ZnO}$ čisti cinkit, ICDD PDF \# 36-1451 te da je uzorak $\mathrm{Fe}_{2} \mathrm{O}_{3}$ čisti hematit, ICDD PDF \#33-0664. Na temelju male širine difrakcijskih maksimuma može se zaključiti da su svi uzorci dobro kristalizirani, odnosno da se sastoje od relativno velikih kristala.

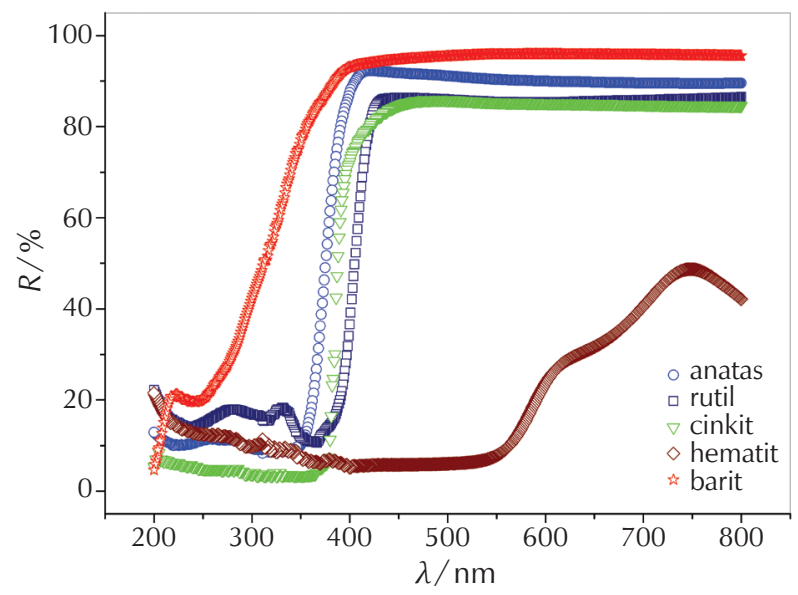

Slika 13 - UV-Vis DRS spektri anatasa, rutila, cinkita, hematita i barita

Fig. 13 - UV-Vis DRS spectra of anatase, rutile, zincite, hematite, and barite 
Kako bi se utvrdila širina zabranjene zone uzoraka, izmjereni su refleksijski spektri u području valnih duljina 200 - 700 nm (slika 13). Spektar je izmjeren i za $\mathrm{BaSO}_{4}$ standard (slika 13). Uzorci posve apsorbiraju zračenje kraćih valnih duljina, odnosno pri tim valnim duljinama reflektancija je bliska nuli, a naglo raste u području prijelaza iz UV u vidljivu svjetlost. Primjenom jedn. 16 UV-Vis DRS spektri transformirani su u Kubelka-Munk funkcije, gdje je pri izračunu $R(\infty)$ kao $\mathrm{R}$ standarda primijenjena reflektancija $\mathrm{BaSO}_{4}$.

Zabranjena zona, $E_{g}$, određena je potom pomoću Taucova grafičkog prikaza (ovisnosti $(F(R) h v)^{\mathrm{n}}$ o $h v$, gdje je $n=1 / 2 \mathrm{i}$ $n=2$ ) (slika 14). Vrijednost eksponenta $n$ govori o prirodi prijelaza elektrona u uzorku te iznosi 2 za direktni i $1 / 2$ za indirektni prijelaz elektrona iz valentne u vodljivu vrpcu. Za sve uzorke obje krivulje ovisnosti, $(F(R) h v)^{1 / 2} \mathrm{i}(F(R) h v)^{2} \mathrm{O}$ $E$, imaju linearni segment. Stoga je moguće odrediti vrijednosti zabranjene zone i za indirektni i za direktni prijelaz svih poluvodiča a taj je pristup čest u literaturi. ${ }^{11}$ Linearni dijelovi dobivenih krivulja ekstrapolirani su na apscisu a energija definirana sjecištem pravca i apscise (tablica 1) odgovara minimalnoj energiji upadnog zračenja dovoljnoj da pobudi elektron s vrha valentne vrpce poluvodiča na skok na dno vodljive vrpce, odnosno energiji koja odgovara zabranjenoj zoni. Treba napomenuti da se početna i završna točka te općenito broj točaka koji se uzima u obzir pri utočnjavanju na jednadžbu pravca odabire arbitrarno, što unosi određenu subjektivnost u sam postupak.

Tablica 1 - Vrijednosti zabranjene zone anatasa, rutila, cinkita i hematita za indirektni i direktni prijelaz određene iz Taucova grafičkog prikaza

Table 1 - Values of the band gaps of anatase, rutile, zincite, and hematite for the indirect and direct transitions determined from the Tauc plot

\begin{tabular}{c|c|c} 
& $E_{\mathrm{g}}$ za indirektni prijelaz $/ \mathrm{eV}$ & $E_{\mathrm{g}}$ za direktni prijelaz $/ \mathrm{eV}$ \\
\hline anatas & 3,20 & 3,41 \\
\hline rutil & 3,00 & 3,11 \\
\hline cinkit & 3,19 & 3,25 \\
\hline hematit & 1,96 & 2,15 \\
\hline
\end{tabular}

U literaturi je moguće naći različite vrijednosti širine zabranjene zone istraživanih poluvodiča. Te razlike pripisuju se varijacijama u čistoći, stehiometriji, veličini kristalita, defektima, vrsti elektronskih tranzicija, kvantnim efektima,
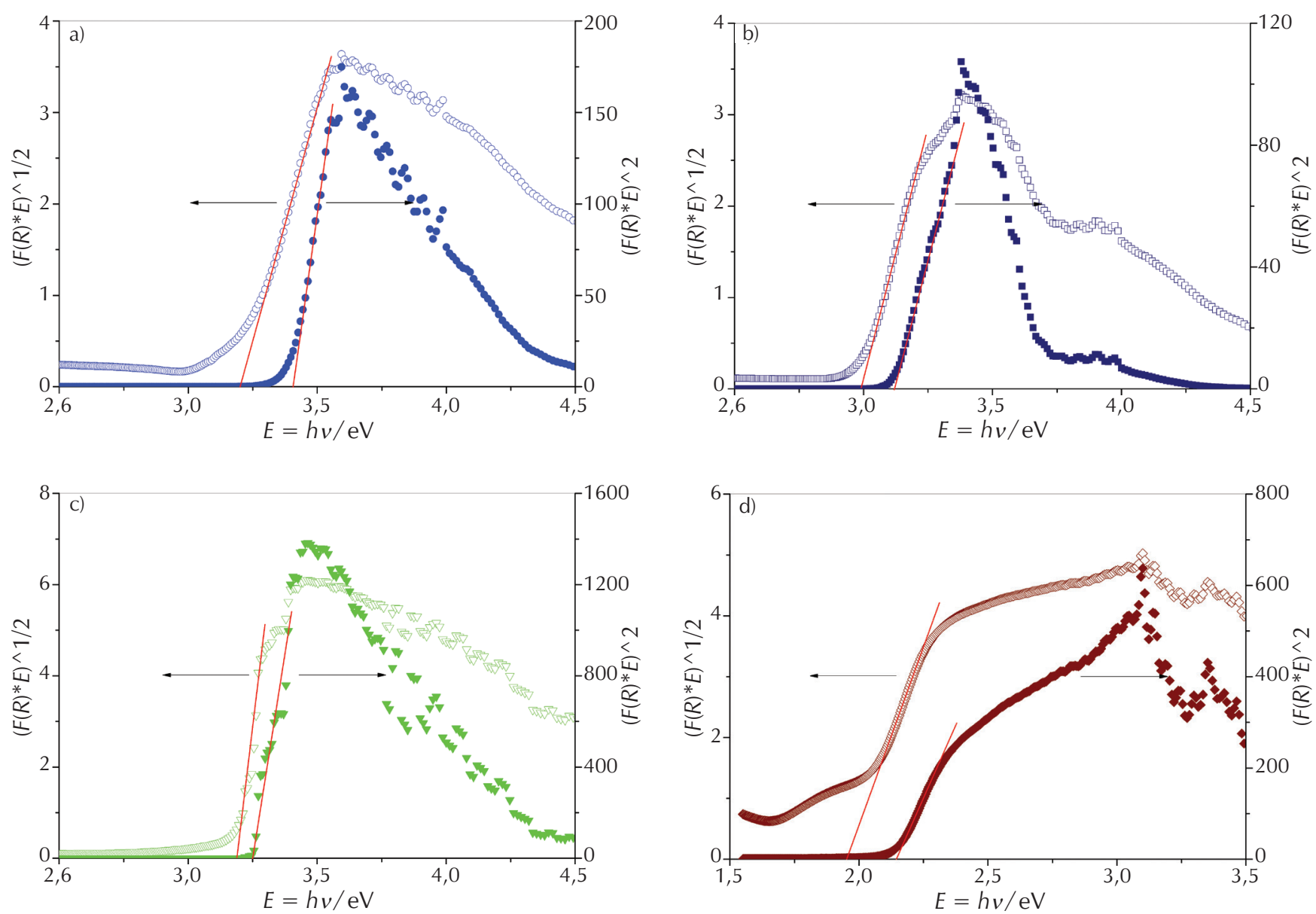

Slika 14 - Taucovi grafički prikazi (ovisnost $(F(R) E)^{1 / 2}$ i $(F(R) E)^{2}$ o $E$ ) za uzorke a) anatasa, b) rutila, c) cinkita i d) hematita

Fig. 14 - Tauc plots (the dependence of $(F(R) E)^{1 / 2}$ and $(F(R) E)^{2}$ on $E$ ) for samples: a) anatase, b) rutile, c) zincite, and d) hematite 
itd. ${ }^{10,12}$ Glavnina autora smatra da je prijelaz zabranjene zone $\mathrm{u}$ anatasu indirektni (odnosno da je anatas indirektni poluvodič), dok se kao širina zabranjene zone anatasa najčešće navodi 3,2 eV. Stoga se slaganje eksperimentalno dobivene zabranjene zone s literaturnom vrijednošću u tom slučaju može ocijeniti izvrsnim. ${ }^{10,13} \mathrm{~S}$ druge strane, rutil karakterizira direktni prijelaz i kao širina zabranjene zone najčešće se navodi $3,0 \mathrm{eV}$, pa se slaganje u tom slučaju može ocijeniti zadovoljavajućim. ${ }^{10,13}$ Cinkit je direktni poluvodič za čiju se širinu zabranjene zone najčešće navodi $3,37 \mathrm{eV}^{14,15}$, pa se i u tom slučaju slaganje može ocijeniti zadovoljavajućim. Hematit se smatra indirektnim poluvodičem sa zabranjenom zonom u području od 1,9 do 2,2 eV ${ }^{12,16}$, te je slaganje dobivene vrijednosti s literaturnim podatkom za hematit također zadovoljavajuće.

Budući da za svaki od istraživanih poluvodiča postoji područje linearne ovisnosti i $(F(R) h v)^{1 / 2}$ i $(F(R) h v)^{2}$ o $E$ (slika 14), očito je da metoda nije naročito korisna pri razlikovanju direktnih od indirektnih poluvodiča. Dapače, dojam je da je mogućnost izračuna širine zabranjene zone za oba prijelaza upravo doprinijela rašomonu o vrsti poluvodiča. U literaturi se tako najčešće računaju vrijednosti zabranjene zone za oba prijelaza, primjerice Mallick i Dash, ${ }^{17}$ a odstupanje od očekivanog rezultata tumači kvantnim efektima, strukturnim promjenama, utjecajem veličine (nano), odnosno površine i morfologijom. ${ }^{13,18}$ Pojedini autori čak zanemaruju utjecaj prisutnosti nečistoća ili amorfne faze u uzorku te pojavu različitih polimorfnih modifikacija.

Metoda je možda najkorisnija pri praćenju promjene širine zabranjene zone u ovisnosti o udjelu dopanta. Naime, poluvodiči poput $\mathrm{TiO}_{2}$ i $\mathrm{ZnO}$ često se upotrebljavaju za fotokatalitičku razgradnju organskih spojeva u otpadnim vodama. ${ }^{10}$ Smanjenje širine zabranjene zone, odnosno proširenje područja u kojem dolazi do apsorpcije fotona u područje vidljivog zračenja, može znatno povećati učinkovitost fotokatalizatora. Stoga se nemali broj istraživanja bavi ugradnjom stranih atoma u kristalne rešetke poluvodiča s ciljem postizanja smanjenja širine zabranjene zone, tzv. crvenog pomaka. ${ }^{14,19}$ Mogućnost tzv. "inženjerstva širine zabranjene zone"15 poluvodiča atraktivna je i u područjima fotokatalitičkog cijepanja vode, fotonaponskih ćelija, pohrane energije, senzorike itd. Pri takvim istraživanjima u pravilu se dobivaju jasni trendovi promjene širine zabranjene zone u ovisnosti o udjelu dopanta. ${ }^{14}$

\section{Zaključak}

U radu je detaljno opisana metoda mjerenja zabranjene zone poluvodiča primjenom difuzne refleksijske spektroskopije. Metoda je primijenjena pri određivanju zabranjene zone anatasa, rutila, cinkita i hematita. Prikupljanje eksperimentalnih podataka može se provesti upotrebom pristupačnog spektroskopskog instrumenta a obrada dobivenih podataka je jednostavna, pa se Taucova metoda može smatrati praktičnim načinom određivanja zabranjene zone poluvodiča. Dobiveni rezultati ipak ukazuju da metoda nije besprijekorna u pogledu točnosti i razlikovanja poluvodiča s indirektnim i direktnim prijelazima.

\section{ZAHVALA}

Ovaj rad je financirala Hrvatska zaklada za znanost projektom broj IP-2018-01-2963, na čemu joj autori zahvaljuju, hvala i Sveučilištu u Zagrebu na kojem je rad izrađen. Zahvaljujemo recenzentima za vrijedne primjedbe i sugestije koje su pridonijele kvaliteti ovog rada. 


\section{Literatura \\ References}

1. W. D. Callister, Materials Science and Engineering, An Introduction, John Wiley and Sons, Inc. New York, 2007.

2. M. Green, Solar Cells: Operating Principles, Technology, and System Applications, Prentice-Hall, Inc., Englewood Cliffs, 1982.

3. D. Harvey, Analytical Chemistry 2.0, Ch. 10. Spectroscopic Methods, URL: http://www.saylor.org/site/wp-content/uploads/2012/07/Chapter1011.pdf.

4. P. M. Amirtharaj, D. G. Seiler, Optical Properties of Semiconductors, Ch. 36, Handbook of Optics, Volume II Devices, Measurements, and Properties, Ed. M. Bass, $2^{\text {nd }}$ Ed., McGraw Hill, 1995., New York.

5. L. K. Lamontagne, Band structures and the meaning of the wave vector $k$, https://www.mrl.ucsb.edu/ seshadri/2018_218/Bands-k-space.pdf.

6. J. Essick, R. Mather, Characterization of a Bulk Semiconductor's Band Gap via Near-Absorption Edge Optical Transmission Experiment, Am. J. Phys. 61 (1993) 646-649, doi: https://doi.org/10.1119/1.17173.

7. J. Tauc, R. Grigorovici, A. Vancu, Optical Properties and Electronic Structure of Amorphous Germanium, Phys. Status Solidi B 15 (1966) 627-637, doi: https://doi.org/10.1002/ pssb.19660150224.

8. K. M. Reddy, S. V. Manorama, A. R. Reddy, Bandgap studies on anatase titanium dioxide nanoparticles, Mater. Chem. Phys. 78 (2002) 239-245, doi: https://doi.org/10.1016/ S0254-0584(02)00343-7.

9. J. L. Taylor, Reflectance Measurements of Materials Used in the Solar Industry, Perkin Elmer Technical Note, http://www. perkinelmer.com/pdfs/downloads/app reflectancemeasurementsofmaterialsusedinthesolarindustry.pdf.

10. S. Valencia, J. M. Marín, G. Restrepo, Study of the Bandgap of Synthesized Titanium Dioxide Nanoparticles Using the SolGel Method and a Hydrothermal Treatment, Open Mater. Sci. J. 4 (2010) 9-14, doi: https://doi.org/10.2174/187408 8X01004010009.
11. M. Meinert, G. Reiss, Electronic Structure and Optical Band Gap Determination of $\mathrm{NiFe}_{2} \mathrm{O}_{4}$, J. Phys. Condens. Matter. 26 (2014) 115503, doi: https://doi.org/10.1088/09538984/26/11/115503.

12. K. Sivula, R. Zboril, F. Le Formal, R. Robert, A. Weidenkaff, J. Tucek, J. Frydrych, M. Grätzel, Photoelectrochemical Water Splitting with Mesoporous Hematite Prepared by a Solution-Based Colloidal Approach, J. Am. Chem. Soc. 132 (2010) 7436-7444, doi: https://doi.org/10.1021/ja101564f.

13. S. Paul, A. Choudhury, Investigation of the Optical Property and Photocatalytic Activity of Mixed Phase Nanocrystalline Titania, Appl. Nanosci. 4 (2014) 839-847, doi: https://doi. org/10.1007/s13204-013-0264-3.

14. E. Gungor, T. Gungor, D. Caliskan, A. Ceylan, E. Ozbay, Co doping induced structural and optical properties of sol-gel prepared ZnO thin films, Appl. Surf. Sci. 318 (2014) 309313, doi: https://doi.org/10.1016/j.apsusc.2014.06.132.

15. A. Janotti, C. G. Van de Walle, Fundamentals of zinc oxide as a semiconductor, Rep. Prog. Phys. 72:126501 (2009) 1-29, doi: https://doi.org/10.1088/0034-4885/72/12/126501.

16. S. Piccinin, The band structure and optical absorption of hematite $\left(\alpha-\mathrm{Fe}_{2} \mathrm{O}_{3}\right)$ : a first-principles GW-BSE study, Phys. Chem. Chem. Phys. 21 (2019) 2957-2967, doi: https://doi. org/10.1039/C8CP07132B.

17. P. Mallick, B. N. Dash, X-ray Diffraction and UV-Visible Characterizations of $\alpha-\mathrm{Fe}_{2} \mathrm{O}_{3}$ Nanoparticles Annealed at Different Temperature, Nanosci. Nanotechnol. 3 (2013) 130-134, doi: https://doi.org/10.5923/j.nn.20130305.04.

18. S. P. Schwaminger, R. Surya, S. Filser, A. Wimmer, F. Weigl, P. Fraga-García, S. Berensmeier, Formation of iron oxide nanoparticles for the photooxidation of water: Alteration of finite size effects from ferrihydrite to hematite, Sci. Rep. 7:12609 (2017) 1-9, doi: https://doi.org/10.1038/s41598017-12791-9.

19. J. Guo, Electronic structure characterization and bandgap engineering of solar hydrogen materials, Proc. SPIE, Solar Hydrogen and Nanotechnology II, 66500F, San Diego (2007), doi: https://doi.org/10.1117/12.734618. 


\title{
EXTENDED ABSTRACT
}

\author{
Determination of the Semiconductors Band Gap \\ by UV-Vis Diffuse Reflectance Spectroscopy \\ Stanislav Kurajica, ${ }^{a *}$ Vilko Mandić, ${ }^{a}$ Marija Tkalčević, \\ Katarina Mužina, ${ }^{a}$ and Ivana Katarina Munda ${ }^{a}$
}

For the application of semiconductors, an important factor is the band gap, i.e., the minimum energy required for the transfer of electrons from the valence to the conduction band. One of the possible methods for band gap determination is diffuse reflectance spectroscopy and Tauc plot. In this paper, an overview of the terms and equations related to the said method is given, as well as its utilization in the determination of band gaps of commercial samples of various metal oxides. Thus, the procedure is demonstrated and evaluated through the determination of indirect and direct band gap values of anatase $\left(\mathrm{TiO}_{2}\right)$, rutile $\left(\mathrm{TiO}_{2}\right)$, zincite $(\mathrm{ZnO})$, and hematite $\left(\mathrm{Fe}_{2} \mathrm{O}_{3}\right)$. All samples were beforehand analysed and identified by X-ray powder diffraction on Shimadzu XRD 6000 diffractometer with CuK $\alpha$ radiation working in a step scan mode with steps of $0.02^{\circ}$ and counting time of $0.6 \mathrm{~s}$. It was determined that all samples are well crystallized with relatively large crystallite sizes. UV-Vis spectra of the samples, as well as barite, which was used as a reference, were obtained on the UV-Vis spectrometer with an integrating sphere in total reflectance mode. The UV-Vis DRS spectra were transformed to Kubelka-Munk function, after which Tauc plot was used for the determination of the indirect and direct band gap values of all samples. The obtained values for anatase were $3.20 \mathrm{eV}$ for indirect transition and $3.41 \mathrm{eV}$ for direct transition, and for rutile $3.00 \mathrm{eV}$ for indirect transition and $3.11 \mathrm{eV}$ for direct transition. The zincite sample showed an indirect band gap of $3.19 \mathrm{eV}$ and direct band gap of $3.25 \mathrm{eV}$, while the obtained indirect band gap value for hematite was $1.96 \mathrm{eV}$ and direct band gap value $2.15 \mathrm{eV}$. As may be seen, the method is not particularly useful when distinguishing direct from indirect semiconductors, since, for all samples, the curves in Tauc plot for both indirect and direct electron transitions possess a linear dependence region from which the band gap value is estimated. However, the obtained band gap values for all the studied semiconductors are in relatively good concordance with literature references. The method is perhaps most useful in monitoring the variation of band gap depending on the dopant content. Namely, the studied metal oxides are used in photocatalysis where the addition of dopants is expected to reduce the band gap to visible light area, and thus improve the photocatalytic activity of the semiconductor. It can be concluded that the Tauc method is not perfect in terms of accuracy and differentiation between indirect and direct electron transitions in semiconductors. Nevertheless, it is a very practical way of band gap assessment for semiconducting materials, because it requires no excessively expensive instrumentation, and the processing of experimental data is rather simple.

\section{Keywords}

Tauc plot, band gap, diffuse reflectance spectroscopy, semiconductors, metal oxides

a Faculty of Chemical Engineering and

Technology, University of Zagreb

Marulićev trg 19, 10000 Zagreb

Croatia

${ }^{\mathrm{b}}$ Ruđer Bošković Institute,

Division of Materials Physics

Bijenička 54

10000 Zagreb, Croatia

Original scientific paper Received September 6, 2019 Accepted September 23, 2019 